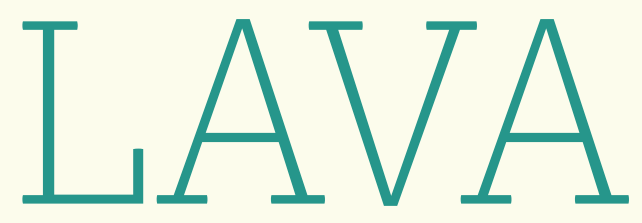

Matéria liquida lançada pelos vulcões.

Torrente, enxurrada, curso. 


\title{
MARGINÁLIA: VANGUARDA E CONTRACULTURA SOB PRESSÃO
}

\author{
- KLEBER PEREIRA DOS SANTOS
}

\section{RESUMO}

Neste artigo são observadas as relações entre vanguarda e contracultura no Brasil no final dos anos 1960 e começo dos anos 1970, particularmente na obra do poeta Torquato Neto.

Palavras-chave: Marginália, vanguarda, contracultura, Torquato Neto, Poesia brasileira

\section{ABSTRACT}

This article observes the relationship between avant-garde and counterculture in Brazil in the late 1960s and early 1970s, particularly in the poet Torquato Neto's work.

Keywords: Marginalia, avant-garde, counterculture, Torquato Neto, Brazilian poetry

"Quando a gente não pode fazer nada, a gente avacalha.

Avacalha e se esculhamba"

O Bandido da Luz Vermelha, Rogério Sganzerla.

"Da adversidade vivemos."

Parangolé - Capa 12. Da adversidade vivemos (1966).

Hélio Oiticica.

\section{I - INTRODUÇÃO}

$\mathrm{N}$

este artigo serão abordados textos que representam os principais dilemas da produção literária do final dos anos 1960 e início dos 1970, um período marcado pela repressão política e pela dissolução dos ideais sociopolíticos que movimentaram a década ante- 
rior no Brasil, especificamente alguns produzidos pelo poeta Torquato Neto (1944-1972).

Nesse período, a literatura, assim como boa parte da cultura nacional, se deu sob condições adversas de sobrevivência. O sufoco, a repressão política dos anos mais agressivos do regime civil-militar (19691975), o período de "ditadura escancarada" (GASPARI, 2002) se tornou uma obsessão para a comunidade de produtores e receptores de literatura. Por vezes, a urgência em responder à altura às circunstâncias sociopolíticas graves do momento foi interpretada por estudiosos da produção literária do período como um dos elementos responsáveis por um suposto baixo nível de realização estética das obras publicadas. A recorrente expressão "vazio cultural" sura política, como pela crise dos projetos utópicos de redenção social, pelo avanço da modernização imposta de forma brutal, pela ascensão dos meios de comunicação de massa e pelo progressivo esvaziamento dos espaços de discussão intelectual e de circulação de atividades artísticas relevantes, deu a tônica para a avaliação negativa das atividades culturais então desenvolvidas. Mesmo a vaga contracultural que se espraiou no Brasil com mais força nos anos posteriores à publicação do fatídico Ato Institucional no 5 é lida normalmente como um efeito colateral do fechamento dos canais "naturais" de expressão política, e não como um fenômeno com características positivas ou inovadoras, quando não foi taxada de representante de um comportamento alienante da apelidada "geração AI-5" (MARTins, 2004). País ruim, poesia pior? Pode ser, mas talvez também haja outros modos de se observar como os artistas do período configuraram tal universo de questões em suas criações, buscando não apenas promover denúncias ou traçar retratos de época, mas colocar em movimento tensões e perspectivas que abrissem possibilidades, janelas, ou, pelo menos, frestas para se respirar em um tempo claustrofóbico.

\section{II - DA TROPICÁLIA À "SUBTERRÂNEA"}

Após o fim dos anos 1960, como consolidado na produção que reflete sobre os anos de autoritarismo militar no Brasil, antecipado em

[1] Título de um artigo de Zuenir Ventura, publicado na revista Visão, em 1971 (VENTURA, 2000, p. 40-51).

[2] Referência ao importante (e polêmico) ensaio de lumna Maria Simon e Vinícius Dantas, "Poesia ruim, sociedade pior", em que se critica a produção poética dos poetas da chamada Poesia Marginal dos anos 1970, publicados nos 1980 (vide bibliografia). 
um ano e pouco com a promulgação do AI-5 em novembro de 1968, de certo modo, encerrou-se o ciclo histórico do nacional-popular no país. O predomínio de um pensamento de esquerda na produção artística, intelectual e em setores consideráveis da imprensa, pertinentemente apontado por Roberto Schwarz no ensaio clássico sobre o período, "Cultura e política, 1964-1969", mesmo durante os governos do marechal Castelo Branco e do general Costa e Silva, pode parecer contraditório, tendo em vista o amplo apoio à "Revolução" responsável por derrubar o considerado perigoso governo do ambivalente presidente trabalhista João Goulart e a inexistência de real resistência ao Golpe, apesar da efervescência dos movimentos populares em prol das Reformas de Base que o antecederam. Se nesses anos pré-AI- 5 uma certa tolerância permitiu o florescer de manifestações culturais de oposição não só à Ditadura, como ao seu projeto político-econômico, à dependência e ao capitalismo, mantendo em essência a mesma análise da conjuntura nacional preexistente ao fatídico primeiro de abril de 1964, como se a derrota tivesse sido um mero tropeço no percurso, afinal se tinha "a certeza na frente, a história na mão"3, com o agigantar-se dos protestos estudantis, engrossados, conforme o avançar da repressão, por vários setores da própria burguesia que apoiou a quartelada contra Goulart, e com o início de ações mais radicais de oposição ao regime, motivando o "álibi" para a assunção da linha dura ao poder e o início de um período de guerra (mais) suja no Brasil com a suspensão de garantias básicas de direitos, esse ideário hegemônico, que já vinha sendo questionado no seio de uma nova esquerda - vide o pensamento maio de 1968 e o não alinhamento tropicalista - sofreu um abalo definitivo, tornando o referencial ideológico das atividades culturais dos anos 1970 bem menos claro do que o da década precedente.

Ressalte-se que o engajamento nacional-popular - por sinal bastante variado em si, indo de posições xiitas defensoras de uma política cultural jdanovista ou de uma arte totalmente submetida à função panfletária, ao ponto de abdicar da pesquisa estética em prol da adoção acrítica e inautêntica de formas populares ${ }^{4}$ até posições mais "esclarecidas", que não enxergavam na ruptura entre forma e conteúdo um caminho para a

[3] Verso de "Para não dizer que não falei das flores", de Geraldo Vandré

[4] Vide a maior parte da produção poética publicada nos volumes de Violão de rua, organizados pelos CPCs e publicados pela Editora Civilização Brasileira e a fase "cordelista" do ex-neoconcreto Ferreira Gullar 
participação do artista nas questões sociopolíticas de seu tempo ${ }^{5}$ - não foi a única corrente artística vigente nos anos sessenta. Os influxos das vanguardas construtivas dos anos 1950 ainda repercutiam fortemente nas artes do período. Dialogando com a pressão das demandas contextuais, como se verifica nos manifestos da Poesia Práxis, no advento do Poema Processo, nas trajetórias dos artistas neoconcretos ou no "salto participante" dos concretistas, as neovanguardas apresentavam resistência ao programa da arte engajada, ao mesmo tempo em que procuravam se desvincular da pecha de formalismo alienado a elas imputado, adotando um "engajamento experimentalista" (Hollanda, 1992, p. 9).

Esse embate eclodiu especialmente nas produções do curto e agitado período entre 1967 e 1968, no momento tropicalista, como prefere denominar Flora Süssekind, ao invés de utilizar o termo movimento, em "Coro, contrários e massa: a experiência tropicalista e o Brasil de fins dos anos 60" (vide bibliografia). Um momento de questionamento radical, pelo humor ou pela agressão, dos discursos correntes da direita e da esquerda, de emergência de demandas antirrepressivas não afinadas com nenhum dos projetos ideológicos que bipolarizavam o mundo dividido da Guerra Fria, em parte em consonância com tendências da juventude internacional (Maio de 68, Revolução Cultura Chinesa, Power Flower, resistência à Guerra do Vietnã e luta dos negros pelos Direitos Civis, Primavera de Praga etc.), inconformada não apenas com a política oficial como preocupada com promover mudanças comportamentais e existenciais, em colocar a imaginação no poder, mudar a vida e transformar o mundo, numa singular união de Rimbaud e Marx. A Tropicália bagunçou o coreto, o andamento do jogo e, se por um lado foi enxergada pela esquerda mais tradicional, leia-se PCB (clandestino, mas atuante), como alienante, mistificadora ou, no mínimo, desprovida de perspectiva global do processo histórico, por outro lado, foi lida como altamente subversiva pelos militares e seus asseclas por provocar no público um ato ameaçador para qualquer regime totalitário, o de pensar. Talvez por isso foi prontamente reprimida como ficou evidente na prisão arbitrária de Caetano e Gil (entre tantas outras detenções de pessoas mais ou menos distantes de aceitar o discurso oficial), logo após a publicação do AI-5.

[5] Como ressalta Celso Frederico em "A política cultural dos comunistas" (vide bibliografia), há consideráveis diferenças internas no modo de conceber a cultura no pensamento de esquerda. O realismo crítico de Lukács é bem distinto da caricatura do realismo socialista, por exemplo. Sobre a relevância da elaboração formal (aqui se tomando uma dicotomia em si questionável entre forma e conteúdo) para o engajamento da obra de arte, tanto os textos de Theodor Adorno quanto de Walter Benjamin destacam que é impossível passar por cima da especificidade da linguagem se se pretende construir um objeto artístico que se queira pertinente do ponto de vista estético e político. 
"The dream is over". E, "quem não dormiu no sleeping-bag nem sequer sonhou"7. Esse era o clima de nuvens escuras nos primeiros anos após o AI- $5^{8}$, pelo menos entre uma parcela da sociedade formada por intelectuais de esquerda, militantes políticos, artistas progressistas, estudantes universitários etc. As cambaleantes certezas ideológicas e esperanças de mudança da desigual realidade brasileira, ainda acalentadas nos primeiros anos da Ditadura, foram atropeladas pela ascensão da linha dura do regime ao centro do poder. O "êxito" da política econômica, impulsionando um processo de modernização veloz do país - apelidada de conservadora - bem distante do sonhado pela intelectualidade dos decênios anteriores, somado ao silenciamento violento das vozes contrárias aos seus métodos e à ofensiva ideológica do Estado sobre a população, apoiada no uso da publicidade, dos meios de comunicação de massa, da educação e mesmo do sucesso futebolístico, contrapunham aos sons provenientes dos porões da repressão a euforia da classe média com o inédito acesso a bens e possibilidades de vida que lhes eram distante até pouco tempo. O discurso oficial desvirtuante dos significados das palavras - algo presente desde os primeiros dias da Revolução, como se nota na simples usurpação desse termo para designar um golpe de Estado - vendia a ideia (e muitos a compraram, acreditando realmente nela ou a adotando cinicamente) de que a manutenção da "paz social" - tida como traço da índole do brasileiro, assegurada pelas medidas de força que os militares eram "obrigados" em seu dever cívico a tomar contra as doutrinas alienígenas: o perigo comunista e a corrupção da juventude, ambas aos seus olhos parte de uma orquestração para subverter o sistema democrático e os valores tradicionais da família brasileira - era a condição fundamental para a continuidade do crescimento do país. Com tal álibi ou carta branca, o governo civil-militar se viu no direito de restringir, ao ponto de quase a extinguir, a relativa liberdade de expressão de formadores de opinião, de setores da política institucional, da classe artística e, principalmente, do movimento estudantil num ataque que fez com que, no espaço de

[6] Trecho da canção “God”, do primeiro álbum solo do ex-Beatles John Lennon, John Lennon/Plastic Ono Band, de 1970.

[7] Trecho de "O sonho acabou", de Gilberto Gil, do álbum Expresso 2222, de 1972.

[8] Por sinal, foi assim transmitido, em forma de previsão do tempo, na primeira página do Jornal do Brasil de 14/12/1968, o que ocorria após a publicação do Al-5: "Tempo negro. Temperatura sufocante. O ar está irrespirável. O país está sendo varrido por fortes ventos. Máx. 380, em Brasília. Mín. 50 nas Laranjeiras” (Apud. VIEIRA, 2011, p. 170). 
poucos meses, o apoio popular às passeatas de 1968 contra os militares se convertesse em silêncio conivente, quando não em denúncias espontâneas de dissidentes aos aparelhos repressivos.

Contraditoriamente, é justo nesse momento que a onda contracultural internacional chega com mais força ao país. A fim de abrir portas da percepção, como queria Aldous Huxley, toda uma geração ${ }^{9}$ - pelo menos, de setores da juventude burguesa - desejosa por romper com grilhões comportamentais, com preconceitos, com cerceamentos aos modos de atuação política e ao livre pensamento, com os dualismos estanques do tipo razão x emoção, arte x vida etc., parte para novas experiências ao som do rock psicodélico e, por vezes, embalada pelo uso de substâncias psicotrópicas. Apesar de apresentar por meio da "grande recusa"10, um posicionamento eminentemente crítico à sociedade tecnocrática ${ }^{11}$ que se tornou onipresente seja no mundo capitalista seja nos países do bloco socialista, esse movimento de "drop out" do sistema destoava, quando não se opunha claramente, do modo tradicional de se pensar a relação entre o sujeito e a ação política, por conta disso sendo visto como voluntarista, escapista ou alienante pelas correntes consolidadas de oposição política da época. Por outro lado, como visto ao se comentar a reação do poder ao movimento tropicalista, o sistema vigente também não enxergava com bons olhos aquela mania de cabeludos, com roupas coloridas, se negando a contribuir ativamente para a sociedade com seus estudos e sua força de trabalho, vagabundeando em coletividades e usando entorpecentes ao som de guitarras distorcidas tão menos agradáveis do que a rebeldia bem comportada dos jovens do iê-iê-iê. Para os adeptos da Lei de Segurança Nacional, aquilo só podia ser parte de uma "guerra psicológica", um modo ardiloso de tentar minar a harmonia da família brasileira, a moral

[9] O processo remonta, na verdade, pelo menos, ao final da Segunda Guerra Mundial, tendo no Existencialismo francês e na Geração Beat norte-americana ancestrais diretos. No Brasil, em São Paulo, no final dos anos 1950 e nos anos 1960 um grupo de poetas foi pioneiro na recepção desse ideário, somado à referência maior surrealista, entre eles Roberto Piva, Claudio Willer, Antonio De Franceschi e Roberto Bicelli.

[10] Conceito de Herbert Marcuse, filósofo alemão, criador de uma simbiose entre marxismo e psicanálise, que influiu fortemente no pensamento da Geração 68.

[11] Uma sociedade tecnocrática é "la sociedade en la cual los que gobiernan se justifican porque se remiten a los técnicos, los cuales, a su vez, se justifican porque se remiten a formas cientificas de pensamiento" (Roszak, 1981, p. 22.), uma sociedade planificada que produz robôs humanos. 
e os bons costumes ${ }^{12}$, atrapalhando o caminho para a consolidação da ordem e a obtenção do progresso.

Na verdade, nos anos 1970 no Brasil, principalmente devido a conjuntura repressiva que marcou os anos que antecederam o início da Abertura na passagem do governo Médici para o do general Ernesto Geisel, mas não exclusivamente por causa disso ${ }^{13}$, a roupa colorida já tinha algo de velho e desbotado ${ }^{14}$. Vivendo sob fogo cruzado, a contracultura era o sub do sub no Brasil, como apontava Hélio Oiticica ${ }^{15}$, pois a própria cultura havia sido relegada a uma posição marginal, com as devidas exceções elegidas pelo poder para representá-la, mumificada, se de acordo com aspectos de sua ideologia nacional-desenvolvimentista ${ }^{16}$. Vivia-se o que ficou consagrado pela expressão, talvez injusta, de vazio cultural. Com as principais vias de circulação de produtos culturais obstruídas ou, no mínimo, rigorosamente vigiadas, o artista se encontrava numa desesperante situação de isolamento - separado até do público restrito ao qual havia se acostumado a dirigir, quanto mais do público mais amplo que por vezes a arte engajada almejara alcançar - que, somada à dissintonia com o espírito da época (a ascendência de valores mercantis e pragmáticos) e à falta de perspectiva de mudança futura, está no cerne de uma arte inconformista como a dos anos finais dos 1960, no entanto, menos tropical, esfuziante, eufórica do que a produção tropicalista. Sai

[12] A censura de cunho moral foi a mais atuante durante o período ditatorial, como apontam diversos estudos como os de Sandra Reimão (Resistência e repressão: censura a livros na ditadura militar) ou Douglas Attila Marcelino (Salvando a pátria da pornografia e da subversão: a censura de livros e revistas nos anos 1970), no entanto, mesmo essa pode ser lida como possuidora de um componente político, pois não há uma separação rígida entre essas esferas, como o conceito de biopolítica de Michel Foucault ajuda a compreender.

[13] Mesmo no exterior, em países em vigência de regimes democráticos, o projeto utópico do Flower Power também já tinha sofrido fortes abalos, assim como as tentativas independentes de insurreição jovem de 1968 não deram frutos políticos concretos.

[14] Menção à canção "Velha roupa colorida", de Belchior, do álbum Alucinação (1976).

[15] “(...) a condição brasileira, mais do que simplesmente marginal dentro do mundo, é subterrânea, isto é, tende e deve erguer-se como algo específico ainda em formação; a cultura (detesto o termo) realmente efetiva, revolucionária, construtiva, seria essa que erguia como SUBTERRÂNEA (escrevi um texto com esse nome, em setembro 69, em Londres): assume toda a condição de subdesenvolvimento (sub-sub), mas não como uma 'conservação desse subdesenvolvimento', e sim como uma... 'consciência para vencer a super paranóia, repressão, impotência...' brasileiras (...)”. OıтıсıсA, Hélio. Brasil diarreia. Disponível em: <http://docslide.com.br/documents/brasil-diarreia. html>. Acesso: dez. 2015.

[16] Não só de repressão viveu a ação governamental no setor cultural. Criações de órgãos culturais como o Conselho Federal da Cultura, a Funarte, a Embrafilme, a investida no projeto de "integração nacional" via telecomunicações com a Embratel, a propaganda massiva do discurso do "Brasil Grande" etc. ilustram o desejo dos militares de vencer a guerra contra a esquerda também no plano da produção simbólica. Em 1972, por exemplo, o regime promoveu a canonização de uma versão desfibrada da ideologia nacionalista e progressista do primeiro modernismo por ocasião do cinquentenário da Semana de Arte Moderna. 
de cena as certezas do engajamento e entra a dúvida, um inconformismo anárquico; sai "Alegria, alegria" e entra "Todo dia é dia D”. A hora já não era a dos iluminados palcos dos Festivais, nem os dos grandes debates públicos provocados pelos filmes do Cinema Novo ou pelas peças de Arena, Opinião, Oficina, nem a da ação política aberta - impossível em um momento em que se reunir com alguém numa esquina já podia render problemas com o Estado policialesco. Hora dos aparelhos clandestinos, das conspirações, de mensagens cifradas, das publicações alternativas, da imprensa nanica, do cinema Super-8; agora vigorava um combate (por vezes, mera tentativa de resistência, sobrevivência) nas trevas ${ }^{17}$.

Esse momento pós-tropicalista, por vezes denominado Marginália, herda da Tropicália sua estética do choque, da violência, inspirada no filme Terra em Transe, de Glauber Rocha ${ }^{18}$, e levada às últimas consequências pelo Teatro Oficina, de José Celso Martinez Côrrea. Desiludido com as propostas pedagógicas da estética nacional-popular e com seu discurso para convertidos, Zé Celso, mais do que o tropicalismo musical (apesar desse também ter enveredado por radicalizar o confronto em alguns momentos como no Festival Internacional da Canção de 1969 e no programa Divino Maravilhoso), mistura o distanciamento brechtiano com a estética da crueldade de Artaud, em peças como $O$ rei da vela e Roda viva, para ofender a moral e o gosto estético do público, pretendendo chocalhar (por vezes, literalmente) uma audiência em essência portadora de valores burgueses, mesmo quando "bem intencionada" e apreciadora de obras de teor sociopolítico crítico. Se num primeiro momento essa guerrilha cultural podia ser aberta, ser construída dentro ainda dos esquemas da grande mídia (televisão, mercado fonográfico), do teatro tradicional e do cinema comercial, com o fechamento político passou a operar num registro extremado, rompendo ainda mais com as convenções artísticas e com seu circuito de circulação. O espetáculo

[17] A referência ao título do livro de Jacob Gorender não visa propor uma equivalência imediata entre as ações de grupos guerrilheiros atuantes nos anos 1970 e as práticas contraculturais, em muitos pontos distintas ou até inimigas, apenas se está observando a similar condição de atuação.

[18] O criador de Câncer, filme que dialoga com alguns aspectos da estética da Boca do Lixo, mas com diferente tom político, manteve relação tensa com os "tropicanalhistas" (mesmo com Caetano, que admirava), como chegou a chamá-los na famosa carta em que elogiou Geisel e afirmou que Golbery era um gênio da raça. (APUD. GaSPARI, Hollanda, Ventura (orgs.), 2000, p. 112). 
conceitual Gracias, Señor, de 1972, passagem do teatro para o te-ato ${ }^{19}$, em íntimo diálogo com as propostas do Living Theater, sem palco, sem texto definido, criação coletiva, totalmente apoiado em improvisação, uma espécie de happening perpétuo, incompreendido pelo público de esquerda, que o taxava de experimentalismo alienado, marginalizado pela própria classe teatral, que não viu com bons olhos a proposta de desinstitucionalização do teatro, e proibido pela Censura, representou esse momento de exacerbação da crise política e cultural.

A antiarte cultivada então, em parte também relacionada a uma crise internacional da arte no pós-modernismo ${ }^{20}$, aqui vincula-se à noção de marginalidade. Marginalidade social da violência dos inchados centros urbanos, marginalidade política diante de um poder panóptico, marginalidade artística em relação às formas de arte consagradas pelas instituições, pela tradição ou pelo consumo. Estampada na bandeira Homenagem a Cara de Cavalo ${ }^{21}$, de Hélio Oiticica, bandido do Morro da Mangueira executado pela polícia, o slogan "Seja marginal seja herói” marca esse momento pós-tropicalista em que um tipo de cinema francamente oposto ao Cinema Novo é apelidado de Cinema Marginal ao ir contra a narratividade representativa, naturalista, da sétima arte. Exaltados por Torquato Neto em sua coluna "Geleia Geral", os filmes do - denominado por seus detratores - cinema udigrudi, de cineastas

[19] "Te-ato é um ato de comunicação direta qualquer. Você encara tudo o que acontece no dia-a-dia como um teatro, onde cada um de nós tem em si uma personagem, e no te-ato você atua diretamente sobre isso. O te-ato é alguma coisa que atua concretamente, fisicamente, na realidade cotidiana. Você o consegue só em raros momentos, mas quando acontece você consegue uma mudança física na relação com as pessoas, na percepção dos corpos. Não é uma coisa de palco. (...) Te-ato é uma atuação exatamente de desmascaramento do teatro das relações sociais. (...) Nesse desmascaramento, o te-ato provoca uma nova consciência física da existência. Não é uma experiência intelectual, mas sim uma experiência com o corpo que passa por uma ação real. É uma coisa mais próxima de Artaud, ou então de macumba, ou de dança primitiva. É alguma coisa que provoca e tem a pretensão de provocar uma mudança física. É através da ação que você chega a mudar alguma coisa. E no te-ato há isso, essa crença de que o homem é que muda o homem" (MARTINEz CorrÉA, 1998. p. 320-321).

[20] De certo modo, o momento interrompido da Tropicália e seus desdobramentos no final dos 1960 e início dos 1970 pode ser considerado o embrião do pós-modernismo no Brasil. Embrião, pois, se alguns elementos como a dissolução de fronteiras entre arte erudita e popular, a fragmentação, a intertextualidade etc., são tipicamente pós-modernos, outros traços como a noção de vanguarda ainda vigente e a perspectiva utópica de transformação o diferenciam do modo como foi descrito por diferentes teóricos que estudaram esse período/ estilo/conjunto de questões que rompe com (ou continua por outros caminhos) o período moderno.

[21] Referindo-se ao Bólide-Caixa 18. Homenagem a Cara de Cavalo, de 1966, Hélio Oiticica explica: "Afora qualquer simpatia subjetiva pela pessoa em si mesma, este trabalho representou para mim um momento ético que se refletiu poderosamente em tudo que fiz depois: revelou para mim mais um problema ético do que qualquer coisa relacionada com estética. Eu quis homenagear o que penso que seja a revolta individual social: a dos chamados marginais. Tal ideia é perigosa mas algo necessário para mim (...) Esta homenagem é uma atitude anárquica contra todos os tipos de forças armadas: polícia, exército etc. (...) reflete uma revolta individual contra cada tipo de condicionamento social." (OITICICA, 1996, p. 101). 
como Ozualdo Candeias, Rogério Sganzerla, Júlio Bressane, Andrea Tonacci, José Agrippino de Paula, José Mojica Marins, Ivan Cardoso e André Luiz Oliveira, em que pese as consideráveis diferenças entre si, são obras iconoclastas, que respondem ao fechamento dos canais de circulação (muitas sequer foram lançadas comercialmente, algumas nem passariam pela censura) com uma estética que muitas vezes não fazia concessões às expectativas do espectador nem apresentavam uma visão redentora da história ou uma crítica facilmente decodificável à situação do país. Um cinema fora-da-lei ${ }^{22}$ que flertava com a marginalidade nos temas, nas formas e na posição em relação ao mercado. Na literatura, um amplo questionamento dos gêneros, das formas, da separação entre arte construtiva, arte engajada e experiência pessoal ${ }^{23} \mathrm{e}$ da própria noção de obra marcam a trajetória de dois nomes de destaque do período, os poetas Torquato Neto e Waly Salomão. Essa estética inovadora e suja dos "malditos", como no plano da música popular ficaram conhecidos alguns artistas que continuaram enveredando pela criação de vanguarda após o Tropicalismo como Jards Macalé, Jorge Mautner, Walter Franco e Sérgio Sampaio, trocou o solar antropófago pelo sombrio vampiro, símbolo recorrente para a bad trip do período. Já não havia espaço para

[22] "1 - Meu filme é um far-west sobre o III Mundo. Isto é, fusão e mixagem de vários gêneros. Fiz um filme-soma; (...) 2 - O Bandido da Luz Vermelha persegue, ele, a polícia enquanto os tiras fazem reflexões metafísicas, meditando sobre a solidão e a incomunicabilidade. Quando um personagem não pode fazer nada, ele avacalha. 3 - Orson Welles me ensinou a não separar a política do crime. 4 - Jean-Luc Godard me ensinou a filmar tudo pela metade do preço. 5 - Em Glauber Rocha conheci o cinema de guerrilha feito à base de planos gerais. 6 - Fuller foi quem me mostrou como desmontar o cinema tradicional através da montagem. 7 - Cineasta do excesso e do crime, José Mojica Marins me apontou a poesia furiosa dos atores do Brás, das cortinas e ruínas cafajestes e dos seus diálogos aparentemente banais. Mojica e o cinema japonês me ensinaram a saber ser livre e - ao mesmo tempo - acadêmico. (...) 11 - Porque o que eu queira mesmo era fazer um filme mágico e cafajeste cujos personagens fossem sublimes e boçais, onde a estupidez - acima de tudo - revelasse as leis secretas da alma e do corpo subdesenvolvido. Quis fazer um painel sobre a sociedade delirante, ameaçada por um criminoso solitário. Quis dar esse salto porque entendi que tinha que filmar o possível e o impossível num país subdesenvolvido. Meus personagens são, todos eles, inutilmente boçais - aliás como $80 \%$ do cinema brasileiro; desde a estupidez trágica do Corisco à bobagem de Boca de Ouro, passando por Zé do Caixão e pelos párias de Barravento. 12 - Estou filmando a vida do Bandido da Luz Vermelha como poderia estar contando os milagres de São João Batista, a juventude de Marx ou as aventuras de Chateaubriand. É um bom pretexto para refletir sobre o Brasil da década de 60. Nesse painel, a política e o crime identificam personagens do alto e do baixo mundo. 13 - Tive de fazer cinema fora da lei aqui em São Paulo porque quis dar um esforço total em direção ao filme brasileiro liberador, revolucionário também nas panorâmicas, na câmara fixa e nos cortes secos. O ponto de partida de nossos filmes deve ser a instabilidade do cinema - como também da nossa sociedade, da nossa estética, dos nossos amores e do nosso sono. Por isso, a câmara é indecisa; o som fugidio; os personagens medrosos. Nesse País tudo é possível e por isso o filme pode explodir a qualquer momento" (SGANZERLA, 2015).

[23] Essa proposta não se confunde com o que veio a ser denominado Poesia Marginal, apesar do modo de circulação e da postura comportamental dessa também ter relações com o conceito, justificando a nomenclatura. Cronologicamente anterior, a produção literária do início da década não apresentava o teor vitalista e a ingenuidade de algumas das propostas de poesia espontânea, expressiva e libertária que veio a caracterizar, em geral, a poesia da Geração Mimeógrafo, apesar dessa descrição nem sempre dar conta da multiplicidade de caminhos da lírica de autores como Charles, Chacal, Cacaso, Ana Cristina Cesar, Francisco Alvim etc. 
a "experiência crítico-experimental coletiva" dos fins dos anos 1960; no "Brasil diarreia” dos anos 1970 só restava a possibilidade de se cooptar, de silenciar ou de partir para arriscadas e radicais ações individuais, muitas vezes aproximadas do desespero, da loucura, do suicídio.

Os textos de Torquato Neto que serão comentados neste trabalho dialogam com esse universo de questões. Possuem como traço comum a marginalidade, a busca por encontrar/criar um entre-lugar, configurar um espaço de resistência, um local de diferença que repete, reage, reelabora sua própria situação na produção de mundos dentro do mundo, não concebidos como espaços de evasão, mas como heterotopias ${ }^{24}$ em íntimo confronto com os espaços normativos, em busca de entender, questionar e, por que não, reescrever o pesadelo da história.

\section{III - “HÁ UM VAMPIRO NA PORTA PRINCIPAL”: NOSTORQUATO"5}

Quem observa as fotos mais antigas do "menino infeliz" ${ }^{26}$ piauiense Torquato Neto, quase sempre com traje social, bem comportado, cabelo curto, aparentando timidez, dificilmente consegue imaginar a desenvoltura e a virulência com que expôs seus sentimentos e suas ideias em textos, poemas e canções. Intimamente ligado ao grupo baiano tropicalista, formado por músicos que conheceu em Salvador alguns anos antes da eclosão do movimento, o poeta iniciou sua trajetória artística no Rio de Janeiro em 1965 como compositor de letras de canções com teor nostálgico e traços da cultura popular nordestina, ao sabor da estética nacional-popular em voga no que então se passou a chamar de MPB, alguns anos após a efervescência da Bossa Nova. Mesmo sua atuação no jornalismo cultural em meados dos anos 1960, como aponta Frederico Coelho em "A formação de um tropicalista: um breve estudo da coluna 'Música popular', de Torquato Neto" (vide bibliografia), seguia a orienta-

[24] Segundo definição de Foucault: “(...) des lieux qui s'opposent à tous les autres, qui sont destinés en quelque sorte à les effacer, à les neutraliser ou à les purifier. Ce sont en quelque sorte des contre-espaces (...) lieux réels hors de tous les lieux (...)” (FoucAult, 2009, p. 24-25).

[25] Menções a trecho da canção "Gotham City", de Jards Macalé e Capinam, defendida no Festival da Canção de 1969 e ao poema-homenagem a Torquato, de Haroldo de Campos, publicado na segunda edição de Os últimos dias de Paupéria.

[26] Trecho da canção "Cajuína", de Caetano Veloso. 
ção de arte engajada ${ }^{27}$, ligada à ideologia dos CPCs da UNE. No entanto, após a conversão de Gilberto Gil aos Beatles e a uma visão mais visceral, menos idealizada (ou manipulada politicamente) da cultura popular, seguida por tentativas frustradas de motivar outros grandes nomes da música para uma renovação de suas composições que se sintonizasse criticamente com a cultura jovem urbana e os novos tempos da indústria cultural internacional, Torquato Neto abraçou com furor, com um radicalismo maior até do que o de Caetano e Gil, a ideia e passou a ser um dos mentores intelectuais ${ }^{28}$ da Tropicália, ao lado de Rogério Duarte e Rogério Duprat, além de ter participação decisiva como compositor ao escrever as letras de músicas como "Geleia Geral" e "Marginália II". A própria ideia de produzir um disco-manifesto, o futuro Tropicália, de 1968, de certa forma, partiu dele, como fica exposto na entrevista que Gil e ele deram a Augusto de Campos (Apud CAmpos, 1968).

Seu envolvimento extremo e consciente talvez o tenha levado a pressentir a reação do sistema autoritário vigente no país às provocações tropicalistas. Com a barra pesada do AI-5, em 1969, Torquato viaja pelos Estados Unidos e Europa e se "autoexila" em Londres por um tempo. Contudo, retorna em 1971 para o Brasil e, já rompido com o grupo baiano, passa a atuar de um modo praticamente isolado na imprensa, em um universo bem menos receptivo do que o do auge do Tropicalismo, em prol de uma resistência poética e política ao estado de coisas vigente. Dessa fase de sua produção, tida como marginal, que se tratará a seguir.

Falar em produção, dessa forma genérica, no caso de Torquato é adequado, pois sua trajetória revela um descompromisso, se não uma desconfiança radical, em relação à noção de obra. Índice disso é o fato de

[27] Torquato, por exemplo, condenava com vigor o ie-ie-iê, a Jovem Guarda, uma "bobagem debilizante" (Apud CALIxTo, 2012, p. 22). Esse processo de mudança foi comum entre os tropicalistas, a grande maioria dos artistas envolvidos no movimento tiveram que se "deseducar" para se livrar de pressupostos estéticos ligados ao pensamento nacional-popular ou de preconceitos de vanguarda em relação à música comercial ou de massa. Caetano Veloso, o mesmo que exaltou Chacrinha no auge do Tropicalismo, mal assistia televisão e não tinha grande simpatia pelo rock até sua irmã, Bethânia, chamar sua atenção para essa "novidade" na cena cultural brasileira, como relata o próprio compositor baiano em Verdade Tropical.

[28] Como comentou Décio Pignatari, Torquato não confundia Zé Celso com Oswald de Andrade, tinha um vasto repertório cultural 
não ter publicado nenhum livro em vida ${ }^{29}$. Seu primeiro poema publicado em revista específica foi na emblemática revista Navilouca, editada por ele e Waly Salomão, mas que não chegou a ver publicada. Também é por Waly Salomão que surgiu a primeira antologia póstuma de seus principais textos jornalísticos, poemas e trechos de diários, Os últimos dias de Paupéria, de 1973. Em vida, seus textos, faróis para a cultura underground brasileira do início dos anos setenta, circulavam em colunas de jornais ou em publicações alternativas.

Foi na sua coluna "Geleia Geral", no jornal Última Hora, que Torquato publicou um de seus textos mais conhecidos:

\section{Pessoal intransferível}

Escute, meu chapa: um poeta não se faz com versos. É o risco, é estar sempre a perigo sem medo, é inventar o perigo e estar sempre recriando dificuldades pelo menos maiores, é destruir a linguagem e explodir com ela. Nada nos bolsos e nas mãos. Sabendo: perigoso, divino, maravilhoso.

Poetar é simples, como dois e dois são quatro sei que a vida vale a pena etc. Difícil é não correr com os versos debaixo do braço. Difícil é não cortar o cabelo quando a barra pesa. Difícil, pra quem não é poeta, é não trair a sua poesia, que, pensando bem, não é nada, se você está sempre pronto a temer tudo; menos o ridículo de declamar versinhos sorridentes. E sair por aí, ainda por cima sorridente mestre de cerimônias, "herdeiro" da poesia dos que levaram a coisa até o fim e continuam levando, graças a Deus.

E fique sabendo: quem não se arrisca não pode berrar. Citação: leve um homem e um boi ao matadouro. O que berrar mais na hora do perigo é o homem, nem que seja o boi. Adeusão! (NETo, 1973, p. 19).

[29] Além de não ter publicado nada em livro em vida, ainda queimou seus manuscritos antes de se suicidar em 1972. Como aponta Fabiano Calixto: "Toda a musculatura da obra torquatiana, portanto, se encontra estilhaçada, em escombros e, acredito, deve ser lida como práticas de escrita, ligadas por camadas diferentes de intensidade que se complementam. Por outro lado é justamente na (e da) aparência grotesca, desleixada e intempestiva, repleta de contradições duras, onde mora a força de seus escritos" (CALIXTo, 2012, p. 8). Interessante observar que a epigrafe do primeiro poema que surge em Navilouca, "Soneterapia", de Augusto de Campos, é o verso de Gregório de Matos "desta vez acabo a obra". 
Nesse texto fica explícita sua concepção de poesia como uma ação que transcende os limites do verso. Se a abolição do quadro levou o construtivismo de Hélio Oiticica e Lygia Clark, progressivamente, à construção de uma arte que ultrapassava as paredes dos museus, deixava de ser exclusivamente uma experiência visual para exigir uma participação mais integral e ativa do corpo dos sujeitos perceptivos, o fim do ciclo histórico do verso, propagado pela trio concretista em seus manifestos, colocou também em questão a poesia, corroendo as fronteiras que a separava de outras manifestações artísticas como as artes plásticas e (por outros caminhos) a música popular, e as que a desvinculavam da vida, seja pela proposta do poema como objeto entre objetos na civilização industrial, seja pela sua concepção como partícipe de lutas sociais, seja pela sua abertura para a participação/criação do leitor. Para Torquato, a composição de letras de canções, a militância no jornalismo cultural, a atuação como diretor e ator em filmes, tudo era poesia, podendo um ato livre de uma pessoa ser algo mais poético do que a publicação de uma coletânea de poemas, por exemplo ${ }^{30}$. O fim da fronteira entre arte e vida representa o ideal contracultural de promover a vida como uma forma de arte, tornar seu próprio corpo - na época, corpo dilacerado por experiências extremas de prazer ou dor - espaço para a experimentação do experimental. Como Waly Salomão explicou para o guarda, em Me segura qu'eu vou dar um troço, "a arte é extensão do corpo" (SALOmão, 2015, p. 69).

Sua prosa fragmentada, veloz, repleta de saltos, lacunas, montagens, vários procedimentos que a aproximam da linguagem poética e da oralidade, com um tom coloquial, mas sem pretensão de reproduzir um falar natural, claramente uma construção de linguagem ${ }^{31}$ - ponto de diferença em relação a algumas experiências posteriores de poesia que fetichizaram a noção de espontaneidade - interpela o leitor, seu "chapa", ao adotar um tom de intimidade para exigir dele um compromisso com a poesia mais profundo do que o de simplesmente continuar a fazer "versinhos". O uso do imperativo destaca o tom propositivo de parte da produção literária de Torquato. Sua coluna, por exemplo, visava, ao invés de sucumbir à paralisia do momento histórico, ser um espaço de resistência

[30] Torquato comenta, por exemplo, que a recusa de Tom Jobim de participar de um Festival, já na fase em que esses estavam esvaziados do conteúdo contestatório de sua fase áurea nos anos 1960, era um ato poético.

[31] "Torquato era um criador representante da nova sensibilidade dos não-especializados. Um poeta da palavra escrita que se converteu à palavra falada, não só à palavra falada idioletal brasileira, mas à palavra falada internacional. (...) Não era de folclorizar a língua” (PIGNATARI Apud Calixto, 2012, p. 20). 
em que se procurava destacar e reunir outras experiências de desafogo e clamar pela resistência ("resista, rapaz", "é preciso não dar de comer aos urubus" etc.) comportamental e política, em sentido amplo, evitando sucumbir ao conformismo ou à melancolia, essa última, sempre às portas de Torquato, como se verá adiante. "Não cortar o cabelo quando a barra pesa" ${ }^{32}$ representa um compromisso ético de resistência contracultural diante da repressão. Como afirmava Hélio Oiticica, "sejamos o não do não" (OıтісісA, 1996, p. 125). Esse "sistema viral ('vírus') de recusa" (CALIXTO, 2012, p. 10) que, contra todos os fatos, procurava agarrar com os dentes um "sonho desesperado" ${ }^{33}$ que escapava, faz parte da faceta solar de sua escrita, pois nessa a recusa é uma forma de afirmar a vida contra todos os condicionantes que a limitam, seja a presença da censura, seja a moral castradora da classe média, seja o comodismo estético de seus pare $^{34}$ etc. A recusa ${ }^{35}$ como uma proposta radical de transformação da arte e da vida, uma defesa anárquica da liberdade em todos os campos.

Essa faceta propositiva de sua escrita se aproxima das experiências de arte ambiental para as quais se encaminharam os neoconcretos Hélio Oiticica e Lygia Clark no mesmo período. O crítico Christopher Dunn, em "'Nós somos os propositores': vanguarda e contracultura no Brasil, 1964-1974"36, comenta que na produção desses artistas e na do poeta Waly Salomão se busca ultrapassar a visão da arte como uma instituição separada da vida, sem, contudo, propagar uma equivalência natural entre ambas, mantendo a tensão ${ }^{37}$, elemento capaz de produzir mudanças em

[32] "O fato é que a farta cabeleira de Torquato fazia parte de uma crítica política da época, como cita Ana Cristina Cesar, em Literatura marginal e o comportamento desviante. Usando cabelos longos, roupas extravagantes, atitudes inesperadas, a crítica política dos jovens [...] passa a ter uma dimensão de recusa de padrões de bom comportamento, seja ela artística ou existencial. Esse dado é uma novidade importante em relação ao modo de fazer política da esquerda tradicional, em que a prática revolucionária deixa de lado os aspectos existenciais e de comportamento, fazendo-se grave, séria, sagrada, conceitual e deserotizada” (RıBEIRo, 2015)

[33] Trecho de "Ai de mim, Copacabana", letra de Torquato Neto, música de Caetano Veloso.

[34] A própria desenvoltura como circulava da letra de música popular ao poema concreto, como "Arco Artefato", mostra a sua disposição a "transar" todas as possibilidades, não se fechar em nenhum programa limitador.

[35] "Com esse raciocínio, sua atuação no campo cultural seria de recusa. Recusar a repressão, a tortura, o aniquilamento, colocar-se na história como sujeito ativo, por isso, as tantas enunciações de proposição ativa: "resista, criatura”, "mantenha os olhos abertos", "não esqueça que você está cercado", "acredite na poesia e viva. e viva ela”, "transe e não se tranque", "não traia”, "preste atenção", "resista” etc. Essa recusa vai costurar todo o tecido artístico de Torquato, formando um painel amplo de resistência poética e política." (CALIXTO, 2012, p. 38).

[36] Vide bibliografia. Obs.: a frase citada no título do ensaio é de Lygia Clark: "(...) Somos os propositores: enterramos a obra de arte como tal e solicitamos a vocês que o pensamento viva pela ação".

[37] Nesse ponto retoma reflexões de Hal Foster em O retorno do real (vide bibliografia). 
ambas. A produção de novas formas de subjetividades, de vivências do corpo e de novos modos de relações intersubjetivas, faz parte de uma micropolítica, da politização do cotidiano, uma proposta de transformar o mundo indissociável da transformação do indivíduo, algo muito presente nos slogans de Maio de 1968 e na negação de uma política que exige o sacrifício do presente para a construção da utopia futura ${ }^{38}$. A antiarte teorizada por Oiticica não visava produzir objetos para contemplação passiva, ela enxergava a necessidade de propor a participação do expectador, abrir espaço para o "elemento vivencial" capaz de tornar a arte um espaço para algum tipo de transformação da sensibilidade, para a mudança do "valor das coisas" ${ }^{3}$.

Por sinal, a ênfase numa arte performativa foi uma das marcas do início da pós-modernidade nas artes. Se isso fica mais claro nas artes plásticas que se encaminharam para o questionamento profundo, em seus artistas mais radicais, do museu - "Museu é o mundo" (OітісіCA, 1996, p. 79) - e passaram a praticar experiências como o happening, procurando envolver cada vez mais o público na construção de uma vivência que pudesse abrir para o espectador-ouvinte outro espaço ${ }^{40}$, na poesia o ressurgimento da voz, da palavra como ação, em situação (o discurso como acontecimento), o distanciar-se do mero decodificar da leitura solitária e puramente visual, enfim, a corrosão da visão tradicional, literária, da mesma, destaca que estava no ar a percepção da necessidade de atravessar as palavras, de buscar uma "corporização do prazer estético"(ZumTHOR, 2007, p. 70).

Seus textos propositivos, essa produção que clama pela resistência do outro e própria ("o poeta não se cuida ao ponto/de não se cuidar"41)

[38] Esse sentimento de urgência, o here and now, está muito presente nos textos torquatianos, sendo uma das características de sua obra que antecipam traços da produção dos poetas da Poesia Marginal ("só quero saber/do que pode dar certo/não tenho tempo a perder" - Poema "Go back", anos depois musicado pelos Titãs).

[39] Menção à frase de Yoko Ono presente no texto "Experimentar o experimental”, de Hélio Oiticica, publicado em Navilouca: "Criar não é a tarefa do artista. Sua tarefa é a de mudar o valor das coisas".

[40] "A condição necessária à emergência de uma teatralidade perfomancial é a identificação, pelo espectador-ouvinte, de um outro espaço; a percepção de uma alteridade espacial marcando o texto. Isto implica alguma ruptura com o 'real' ambiente, uma fissura pela qual, justamente, se introduz essa alteridade" (ZuмTHoR, 2007, p. 41).

[41] Trecho de "O poeta é mãe das armas". Por sinal, é uma característica de sua produção a circularidade evolutiva, espiral, de temas/ obsessões/frases que surgem de diferentes modos nos textos jornalísticos, poemas, poemas visuais, trechos de diários, letras de música, roteiros, filmes em que atua ou por ele produzido etc. Vários dos temas e frases de "Pessoal intransferível" estão no poema citado, publicado em Últimos dias de Paupéria, assim como na "versão visual" de alguns dos versos desse poema, publicada na revista Navilouca. 
é característica de sua busca por espaço ${ }^{42}$ para respirar ("ar em primeiríssimo lugar"), nem que seja nas frestas do sistema, na marginalidade. Em sua coluna, foi recorrente a defesa do Cinema Marginal, dos filmes em Super-8, do terrir ${ }^{43}$ de Ivan Cardoso, das produções da Belair contra as agressões dos cineastas do "falecido Cinema Novo" e contra o fechamento do mercado a tais produções (além da censura que tornava inviável a exposição de boa parte dessas obras). Essa defesa, que ultrapassou as palavras indo para um envolvimento direto com os criadores e com o cinema, não foi fortuita. O Cinema Marginal, como analisa Ismail Xavier, rompe, assim como o havia feito a Tropicália, com as utopias sociais e políticas da arte engajada, aqui representada pelo Cinema Novo, e parte para uma estética experimental e violenta que se contrapõe tanto ao cinema comercial ao romper com a narratividade mimética, ao adotar uma estética anti-ilusionista, como com alguns padrões do cinema de arte ao flertar com o kitsch, com o cinema de gênero etc. ${ }^{44}$ Nesses filmes, a marginalidade não é mais vista por uma perspectiva sociológica; nos filmes de Júlio Bressane, por exemplo, os bandidos "não reivindicam justiça, não proclamam sua crueldade como retaliação tipo 'olho por olho', nos moldes do bandido social de Glauber, não fazem do passado uma justificação do presente, não projetam um destino social a partir de sua opção de violência" (XAVIER, 1993, p. 196). O inconformismo adota um tom anárquico, que questiona o poder e a moral vigente, mas também as explicações totalizadoras e redentoras da esquerda tradicional.

Nos textos do "anjo torto" Torquato, assim como em muitas outras produções da época, essa posição alternativa, à margem (por pressão

[42] "Ocupar espaço: espantar a caretice: tomar o lugar: manter o arco: os pés no chão: um dia depois do outro" (TORQUATO NETO APUD RibeIRo, 2015). Waly Salomão também enxergava a poesia como criação de condições.

[43] O termo foi cunhado por Haroldo de Campos que exaltou o "monstrutivismo" do cinema de Ivan Cardoso em "Ivampirismo: o cinema em pânico". O que pode parecer atualmente inusitado, essa exaltação do cinema de terror, em plano internacional muitas vezes tido por gênero comercial e menor, por partes de poetas de vanguarda, naquele momento no Brasil era compreensível, pois representava um uso inventivo do kitsch, uma inovação, apropriação de algo sem tradição nacional, que se estava criando por aqui, com características próprias, muitas devido às limitações técnicas de uma indústria cinematográfica quase inexistente, por vezes com humor antropofágico, intencional ou involuntário, sendo uma forma de cinema de "play-invenção", como disse Oiticica sobre Nosferato no Brasil, e reconhecia, por exemplo, Décio Pignatari, que também fez experiências com gêneros kitsch como as histórias em quadrinhos e a fotonovela na época. Mesmo Glauber nunca poupou elogios ao cinema de José Mojica Marins, o Zé do Caixão.

[44] Comentando sobre O bandido da luz vermelha: "A estocada aqui vai além dos deslocamentos paródicos de estilo e tema. O gesto agora é a banalização do movimento como fenômeno social, agressão que expressa o antagonismo de postura (o gosto pelo imaginário dos tough guys, individualistas incuráveis, contra um cinema de explicações sociológicas) e um sarcástico toque 'realista' de quem faz comédia com a impotência, exibe uma consciência mais cética das relações entre política e cultura no universo da mercadoria” (XAVIER, 1993, p. 96). 
contextual e/ou por escolha consciente) do que se pode denominar Marginália, encontrou na figura do vampiro uma de suas principais formas de representação. Se no solar período tropicalista, predominou, não sem momentos de eclipse, a ideia do antropófago oswaldiano, no pós-AI-5, um momento de "dispersão geral", como bem nota, entre outros estudiosos, Flora Süssekind, o imaginário do artista como um morto-vivo, figura louca e inadaptada procurando sobreviver na escuridão, um alvo em potencial ${ }^{45}$, esteve no pensamento e nas produções de vários artistas como Zé Celso, Hélio Oiticica, Jorge Mautner, Caetano Veloso, Jards Macalé, Ivan Cardoso etc ${ }^{46}$. Desse último é a mais explícita manifestação do vampirismo no período, o filme Nosferatu no Brasil, de 1971, em que o protagonista é encarnado pelo poeta piauiense.

É possível, no caso de Torquato, interpretar a presença dessa simbologia por dois caminhos, no mínimo, que não são excludentes, mas também não são exatamente complementares. $O$ primeiro está ligado à noção de resistência, à marginalidade como uma forma de se opor ao sistema, marcar a radicalidade de sua opção por não trair, o desejo por "desafinar o coro dos contentes" ${ }^{47}$. Presente no ideário contracultural, revela o desejo de sair fora do sistema, de adotar um comportamento desviante tido pela sociedade como loucura; mais do que ser taxado de louco, assumir e utilizar a "loucura" como bandeira ${ }^{48}$. Nessa perspectiva, antes ser um monstro erótico se esgueirando por becos em noites escuras à procura de vítimas ${ }^{49}$ para saciar sua sede eterna por prazer e sangue, do que ser um sujeito que é levado ao matadouro e berra menos do que um boi. Uma proposta de fidelidade à radicalidade, de não aceitar a média, de não compactuar (seja com o sistema político, seja com a moral

[45] Em Navilouca, sobre uma das imagens de Torquato é sobreposta uma mira formada pelo número quatro. Outro quatro é sobreposto sobre quatro reproduções de um homem assassinado, reforçando a identificação simbólica entre a figura do poeta e a marginalidade. Essa imagem, por sinal, remete diretamente aos trabalhos de Oiticica que se utilizam da imagem do bandido Cara de Cavalo, já mencionados anteriormente. Por sinal, sua única experiência como cineasta underground, Terror da vermelha (1972) também gira em torno da figura de um marginal.

[46] "Tais vampirizações-em-série sublinhariam tanto uma perda da dimensão coletiva, ritual, da devoração no novo contexto político, quanto uma redefinição de status do artista (não mais antropófago, mas uma espécie ávida de morto-vivo) e de sua atividade (cujo caráter é agora secreto, noturno) no Brasil dos anos 70" (SüsSEKIND, p. 54).

[47] Trecho de "Let's play that", poema musicado por Jards Macalé.

[48] Não se está aqui dizendo que ele não tinha problemas reais com o alcoolismo e a depressão, tanto que teve algumas passagens por clínicas psiquiátricas ao longo de sua curta existência.

[49] Ironicamente, o filme de Ivan Cardoso é todo filmado de dia, em pleno verão carioca, em espaços abertos. 
da classe média, seja com as instituições de legitimação cultural, seja com o mercado etc.), de aceitar a destruição apenas como etapa para a construção de algo novo ${ }^{50}$, que não deixava de ter um viés guerrilheiro quase suicida, kamikaze.

Esse viés suicida leva ao segundo caminho para compreender a sua fascinação pela figura do príncipe das trevas ${ }^{51}$. Desde suas primeiras composições, antes do advento da Tropicália, já era possível perceber na obra de Torquato uma linha nostálgico/melancólica sensivelmente destacada ${ }^{52}$. Oriundo de Teresina, sua "Tristeresina", sua infância e parte de juventude se dão num ambiente de valores tradicionais e próximos ao universo rural. A posterior assimilação febril de uma cultura moderna e de posturas comportamentais progressistas não se deu sem tensões, foi, nos dizeres de Viviana Bosi, "um desraizamento ao mesmo tempo temido e desejado" (Bosi, 2014, p. 33). Sem tentar aprofundar a questão, algo que não é o objetivo desse artigo, é possível relacionar a produção, por assim dizer, ciclotímica de Torquato, o embate entre pulsão de vida e pulsão de morte, que mescla uma combativa euforia com momentos de profundo desespero e vontade de desistir, com esse conflito entre passado e futuro, entre tradição e modernidade, culpa por abandonar suas raízes e desejo de ir até o fim em sua revolução pessoal ${ }^{53}$. A letra da canção "Mamãe, coragem" pode ser considerada emblemática desse processo, em que uma ironia com a cultura brega e com o estilo de vida da dona de casa, a mãe ("Peque uns panos pra lavar/Leia um romance/Veja as contas do mercado/Pague as prestações"), e as reiteradas afirmações do eu lírico de que escolheu a vida citadina e moderna ("Eu quero eu posso eu fiz eu quis") não escondem uma necessidade de se justificar e laços sentimentais com esse passado que não pode simplesmente apagar.

Esse aspecto noturno de sua produção, a identificação com o vampiro via flerte com o ctônico, sua radical solidão e condenação a viver nas trevas, se intensifica, principalmente, após a experiência de exílio e

[50] “(...) desse caos vietnamesco é que nascerá o futuro, não do conformismo e do otarismo” (OıтıсıсA, 1996, p. 83).

[51] "Ivan Cardoso me anima com seu filmes de vampiros, logo a mim, vidrado em vampiros" (Torquato Neto Apud Calixto, 2012, p. 50).

[52] Vide "Pra dizer adeus", letra para canção de Edu Lobo, por exemplo.

[53] Ressalte-se que não era uma experiência individual apenas. Durante os anos de modernização conservadora, esse drama configurou aspectos da subjetividade de mais de uma geração no Brasil, devido tanto ao êxodo rural e à explosão demográfica dos centros urbanos quanto ao fosso que se abriu entre gerações motivado pelas radicais diferenças de concepção de mundo de parcela da juventude em relação as de seus pais. 
a compreensão/introjeção do significado profundo do AI-5, uma "noite escura" ${ }^{54}$ desabando sobre sua geração, como é possível depreender de suas últimas produções, como os diários de Engenho de Dentro ${ }^{55}$ ou o poema "Literato cantabile":

\section{Literato cantabile}

Agora não se fala mais

toda palavra guarda uma cilada

e qualquer gesto é o fim

do seu início

agora não se fala nada

e tudo é transparente em cada forma

qualquer palavra é um gesto

e em minha orla

os pássaros de sempre cantam assim,

do precipício:

a guerra acabou

quem perdeu agradeça

a quem ganhou.

não se fala. não é permitido

mudar de ideia. é proibido.

não se permite nunca mais olhares

tensões de cismas crises e outros tempos

está vetado qualquer movimento

do corpo ou onde que alhures.

toda palavra envolve o precipício

e os literatos foram todos para o hospício.

e não se sabe nunca mais do fim. agora o nunca.

agora não se fala, sim. fim, a guerra

acabou

[54] "Uma noite escura sai de mim e vem descer aqui/sobre esta noite maior e sem fantasmas./como não morrer de medo se esta noite é fera/e dentro dela eu também sou fera e me confundo nela e ainda insisto?" (Torquato Neto Apud Ribeiro, 2015).

[55] "Anotação de 9/10: (...) deus está solto e foi caetano quem gritou primeiro. posso reconhecê-lo em seus disfarces e vou ao seu encontro como - exatamente - sei que vou morrer. lá fora, os piores dias são todos, principalmente quando me custam vinte quatro horas de medo, de solidão e monólogos (...)". (NETO, 1973, p. 59). Engenho de Dentro é o bairro em que se localizava o Hospital Psiquiátrico Pedro II, no Rio de Janeiro. 
e quem perdeu agradeça a quem ganhou.

(NETO, 1973, p. 35).

Nesse poema o fechamento, o sufoco, o "estado de pânico e paralisia" (SÜSSEKIND, 1985, p. 28), a cultura da derrota que marcou o início da década de 1970, segundo Renato Franco (1998, p. 24), enfim, "as transas difíceis desse tempo" (Torquato Neto Apud Calixto, 2012, p. 69) surgem de modo inequívoco. A falta de saída suplanta a busca por frestas para respirar dos textos de sua cruzada na militância contracultural, nos quais predomina uma paixão pela vida, pela ação. Contudo, a morte, o desencanto, sempre foi uma presença constante em seus textos, vide "Cogito" ("eu sou como sou/vidente/e vivo tranquilamente/todas as horas do fim"), seu poema mais conhecido, passando por algumas composições da fase tropicalista, como "Marginália II" ("Eu, brasileiro, confesso/Minha culpa, meu degredo/Pão seco de cada dia/Tropical melancolia/Negra solidão") ${ }^{56}$. Em "Literato cantabile", ela não é mencionada, contudo, parece estar à espreita ao fim de cada verso, tal a atmosfera opressiva, apocalíptica, desenhada, onde nada mais é possível, a imobilidade impera, mesmo a palavra é uma cilada, um precipício; a única porta é a da saída ${ }^{57}$.

Em sua carta de despedida, antes de fechar todas as passagens de ar e abrir o gás do aquecedor, a figura sombria que surge não é a do vampiro, mas a de outra representação de um ser morto-vivo, a múmia ("sou uma grande múmia”). Mais do que fazer uma crítica biográfica, voltada para a canonização do poeta-suicida ${ }^{58}$, de aura romântica, o que interessa é flagrar a possibilidade dupla da simbologia marginal dessas figuras de assombração: o modo como a posição marginal pode tanto ser um posicionamento tático para a resistência ao status quo como pode

[56] Observe-se que mesmo na canção-manifesto "Tropicália", de Caetano Veloso, os "urubus passeiam entre os girassóis". Por trás do colorido e das "bananas ao vento", havia uma percepção da tragédia, que ficava em segundo plano devido ao aspecto utópico de transformação que ocupava o primeiro plano, num momento em que ainda era possível alimentar um sonho desesperado. No período pós-tropicalista, há um sentido amplificado dessa tragédia, um momento de "revisões amargas, de lacunas e de silêncio, que era sem dúvida autofágico" (André Bueno Apud Calixto, 2012, p. 39)

[57] “Escorpião encravado/Na sua própria ferida/Não escapa, só escapo/Pela porta da saída" - Versos de "Todo dia é dia D", de Torquato Neto. Antes do suicídio derradeiro, segundo Paulo de Andrade, o poeta tentou outras cinco vezes se matar. Como disse Leminski, "a vida pesada nas mãos de uma criança".

[58] Beatriz de Moraes Vieira reflete sobre as implicações sociais desse ato: há "uma relação entre suicídio e a vida social e histórica, uma vez que se trata da eliminação de um corpo que ao mesmo tempo é social e coletivo, uma escolha subjetiva em meio a determinações do corpo social" (VIEIRA, 2008, p. 28.). O suicídio está intimamente ligado a uma fragmentação da experiência subjetiva que não é um traço apenas pessoal, tanto que foi uma constante geracional casos de loucura e/ou suicídio interrompendo trajetórias e projetos no período. 
ser uma situação-limite a qual é levado o sujeito, autodestrutiva. Essa ambiguidade perpassa a interpretação do significado das produções da Marginália como um todo, por vezes tidas como revolucionárias, em outras leituras consideradas simplesmente niilistas.

\title{
IV - CONSIDERAÇÕES FINAIS
}

\author{
"Marginal é quem escreve à margem" \\ - Paulo Leminski ${ }^{59}$ \\ “(...) e nesta margem da margem há pelo menos margem (...)” \\ - Haroldo de Campos. ${ }^{60}$ \\ "A gente deixou de marginal para ser magistral."
}

- Chacal. ${ }^{61}$

As três citações que abrem o breve encerramento desse artigo indicam reflexões sobre a questão da marginalidade da palavra poética. É possível afirmar que a poesia em si é um ato marginal, como ressalta Dominique Maingueneau, por exemplo, ao destacar o aspecto parasitário, paratópico, da linguagem literária, um discurso que nunca está totalmente integrado na sociedade, mas que também não é um objeto autônomo, independente. Por sinal, a descrição da poesia como um elemento inadaptável e incômodo remonta à expulsão dos poetas

[59] LEMINSKI, 2013, p. 213. Paulo Leminski não apreciava ser relacionado à Poesia Marginal, a qual realmente não pertencia propriamente, e costumava a criticar em alguns de seus ensaios e cartas: "Não vejo consistência na poesia marginal. Você pode até ser contra a poesia concreta, mas pelo menos ela tem o mérito de ser clara" (PAULo LeminskI APUD VIEIRA, 2008, p. 79). Mesmo uma aproximação de sua poética com as dos (pós-)tropicalistas Torquato Neto e Waly Salomão, com as quais apresenta maiores pontos de contato, precisa ser feita com cuidado. Por outro lado, sua persona foi a própria encarnação do "poeta marginal"; segundo Toninho Vaz, ele se recusava até a ter carteira de identidade...

[60] Trecho do texto de Haroldo de Campos em Navilouca. A presença do excerto da prosa de Galáxias, assim como dos textos de Décio Pignatari e Augusto de Campos mostram a singularidade da publicação no cenário cultural brasileiro e desse momento da arte nacional, apesar de todas as condições adversas vigentes. A aproximação da vanguarda construtiva, nos concretos, eminentemente racional, pelo menos em sua fase ortodoxa/heroica, ao neoconcreto Hélio Oiticica e ao universo contracultural, marcado por uma postura irracionalista e anti-intelectual, na revista representado por Jorge Salomão, Rogério Duarte, Chacal, entre outros, é algo exemplar da tentativa inovadora de buscar sínteses entre experimentalismo formal erudito e revolução comportamental jovem, por outro lado, demonstra os impasses dessas propostas para se sustentarem no cenário sociopolítico brasileiro adverso isoladamente, uma busca por encontrar saídas e novos caminhos.

[61] Depoimento de Chacal. Disponível em: <http://www.sescsp.org.br/files/edicao_revista/4f1acc98-8dc2-4f26-b52c-48c67a96ba6f. pdf.> Acesso dez. 2015. Chacal costuma revelar em entrevista certo desconforto com a institucionalização da Poesia Marginal, que se deu a partir dos anos 1980, ao mesmo tempo em que não vê isso como uma negação da experiência coletiva e underground dos grupos como Nuvem Cigana nos anos 1970. 
em A República, de Platão. Jacques Derrida, em A farmácia de Platão, destaca a indecência da escrita para o filósofo grego, interpretando os sentidos da palavra phármakon utilizada para caracterizá-la, ao mesmo tempo remédio e veneno, algo presente e ausente, nem verdade e nem mentira, uma antissubstância ambígua e suplementar. Talvez, por isso, caracterizar os textos poéticos de um momento histórico específico como marginais pareça problemático aos olhos de vários poetas, inclusive alguns que foram classificados como marginais por aspectos de suas obras. Conceito múltiplo, que pode estar se referindo a diferentes tipos de marginalidade ${ }^{62}$, por vezes antagônicas (a marginalidade dos contos de João Antônio pouco tem a ver com a marginalidade dos poemas de Charles, que, por sua vez, apresentam uma estética muito distinta da encontrada nos trabalhos de Waly Salomão) ${ }^{63}$, o rótulo "marginal", se visto como uma essência, uma identidade, pode ser limitador, pois a ideia de margem é intimamente dependente da noção de centro. Só há marginal à margem de, em relação a. Seu potencial desestabilizador, desterritorializador ${ }^{64}$, está na percepção/manutenção dessa provisoriedade, seu aspecto tático, a necessidade de estar sempre se modificando conforme o eixo se movimenta e não em adotar a marginalidade como um valor em si, a substituir outro, uma mera troca de posições.

A identificação com a postura marginal nos anos 1970 foi uma escolha, nos principais artistas, consciente que buscava marcar "o não pertencimento às estruturas sociais hegemônicas e autoritárias, representando a não integração ao modelo de modernização conservadora perpetrado pelo Estado de forma autoritária e excludente" (PATRocínio, 2015, p. 7), assim como a não identificação com alguns dos discursos totalizantes que o questionavam. Com mudanças nas condições sociopolíticas a partir do processo de Abertura, com a distensão da pressão histórica, muitas dessas posturas precisaram ser reavaliadas, para se evitar o risco da mumificação da transgressão. A trajetória de Waly Salomão, poeta

[62] Paulo Roberto Tonani do Patrocínio distingue três tipos de marginalidade: os marginais da editoração, criadores que fogem aos padrões normais de editoração, distribuição e circulação; os marginais da linguagem, que buscam subverter registros estéticos consolidados; e os marginais por tentarem apresentar a fala de setores excluídos ou marginalizados da sociedade (PATRocínIo, 2015).

[63] Isso sem entrar no mérito do ressurgimento do termo literatura marginal nos anos 2000 para caracterizar não mais uma literatura em que a marginalidade social era tema de escritores de outras classes sociais, que se acreditavam com procuração para falar pelo sujeito marginalizado, mas para denominar uma literatura escrita por pessoas da (ou oriundas da) periferia.

[64] “(...) se o escritor está à margem ou à distância da sua frágil comunidade, a situação coloca-o mais à medida de exprimir uma outra comunidade possível, de forjar os meios de uma outra consciência e de uma outra sensibilidade” (Deleuze \& GUATTARI, 2003, p. 40). 
bastante consciente dos limites da experiência contracultural dos anos $1970^{65}$, sem deixar de manter até o fim dela uma postura eminentemente provocadora e insubmissa, é emblemática dessa dimensão contextual da marginalidade, da necessidade de se perceber que, por exemplo, um retorno ao livro e ao verso "clássico" pode, em dada circunstância, ter um potencial transformador maior do que a reprodução de uma fórmula de espontaneidade e descompromisso (que, diga-se de passagem, nunca foi a praia de Torquato ou de Waly, mesmo que o tom coloquial de alguns de seus textos possam passar essa impressão) fora da circunstância em que ela fez algum sentido ${ }^{66}$.

Da Marginália, desse momento pós-tropicalista duro, difícil, mas não vazio, há que se extrair menos uma estética a ser preservada ou reproduzida do que uma postura diante da arte e da vida. O experimentalismo estético e comportamental da poesia de Torquato Neto, que transborda dos recipientes tradicionais em que se costumava circunscrever a experiência poética para estendê-la para todos os campos de atuação do sujeito, revela a crença de que, nos dizeres de Henri Meschonnic, "somente há poema se uma forma de vida transforma uma forma de linguagem e, de maneira recíproca, se uma forma de linguagem transforma uma forma de vida" (Meschonnic, 2015, p. 1). Como dizia Leminski, "para ser poeta é preciso ser mais que poeta" (PAUlo Leminski Apud Oliveira, 2015), ir muito além de fazer versinhos ${ }^{67}$ - o que não significa desconsiderar o trabalho com a linguagem, com o qual Torquato esteve compromissado em todos seus escritos, inclusive nos diários de Engenho de Dentro ou mesmo ao elaborar sua carta de despedida, ou acreditar na naturalidade da experiência de vida, apostar numa ingênua poética da expressão

[65] Vide seu depoimento no ciclo de palestras promovido pelo Itaú Cultural em 2001 sobre os anos 1970.

[66] "O prosseguimento daquela atitude, hoje, só leva ao fechamento em guetos. É o que chamo de operação boomerang. A energia desencadeada volta-se violenta contra a matriz. Isso seria para mim a "degenerescência" da contracultura. O oposto disso (...) seria a sensibilidade de abrir janelas para o exterior (...) Éramos os danados da terra, logo estávamos com eles. Agora, evidentemente, temos que partir para outra coisa. Porque o feitiço vira-se contra si mesmo. Sabemos que não podemos nos confinar. Temos que, num bom trabalho de engenharia, construir pontes que liguem tal margem àquela outra, evitar a própria margem, saber que o destino dos bons rios é transbordar e não se confinar" (WALY SAlomäo ApUd GASPARI, HollandA \& VentuRA (orgs.), 2000, p. 260). Entrevista de 1984, publicada por Heloísa Buarque de Hollanda.

[67] "A poesia é, por essência, mais do que e algo de diferente da própria poesia. Ou antes: a própria poesia pode perfeitamente encontrar-se onde não existe propriamente poesia. Ela pode mesmo ser o contrário ou a rejeição da poesia, e de toda poesia. A poesia não coincide consigo mesma: talvez essa não-coincidência, essa impropriedade substancial, aquilo que faz propriamente a poesia." (NANCY, s/d., p. 10-11). 
("a pureza é um mito"68). A poesia é a produção de subjetividades novas, em devir, "vialinguagem" ${ }^{69}$, contra todas as formas de essencialização, limitação, do sujeito, das relações interpessoais, da ética, do político, por meio da recusa, uma longa lista de recusas, por vezes doloridas, talvez fatais: "Para um poema, é preciso aprender a recusar, a trabalhar toda uma lista de recusas. A poesia não muda senão se a recusarmos. Assim como o mundo só muda por aqueles que o recusam" (MESCHONNIC, 2015, p. 6). Encabeçando a lista, a recusa da separação entre arte e vida, o risco maior. Mas, poesia é risco e "quem não se arrisca não pode berra". I

[68] Frase presente na instalação Tropicália, de Hélio Oiticica.

[69] "VIAGEM/LÍNGUA/VIALINGUAGEM" (Neto, 1973, p. 108). 
KLEBER PEREIRA DOS SANTOS - Mestre e doutorando em Teoria Literária e Literatura Comparada pela Faculdade de Filosofia Letras e Ciências Humanas FFLCH-USP, São Paulo-SP, Brasil. kle.santos@uol.com.br. Esse artigo foi produzido para a conclusão do curso "Faces da Poesia Brasileira a partir dos anos 1960", ministrado pela profa. Dra. Viviana Bosi no segundo semestre de 2015. 


\section{REFERÊNCIAS}

ANDRADE, Paulo. Torquato Neto - uma poética de estilhaços. São Paulo: Annablume/FAPESP, 2002.

BASUALDO, Carlos (org.). Tropicália: uma revolução na cultura brasileira. São Paulo: Cosac Naify, 2007.

BOSI, Viviana. Torquato Neto: "Começa na lua cheia e termina antes do fim". In: Revista Literatura e Sociedade, n. 19. São Paulo: FFLCH/USP, 2014, p. 32-56.

CALIXTO, Fabiano Antonio. Um poeta não é feito de versos: Tensões poéticas na obra de Torquato Neto. São Paulo: USP, 2012.

CAMPOS, Augusto de. O balanço da Bossa e outras bossas. São Paulo: Perspectiva, 1968

COELHO, Frederico. A formação de um tropicalista: um breve estudo da coluna "Música popular", de Torquato Neto. Disponível em <http://bibliotecadigital. fgv.br/ojs/index.php/reh/article/viewFile/2171/1310>. Acesso em dez. 2015.

DELEUZE, Gilles; GUATTARI, Félix. Kafka. Para uma literatura menor. Trad. Rafael Godinho. Lisboa: Assírio e Alvim, 2003.

DERRIDA, Jacques. A farmácia de Platão. São Paulo: Iluminuras, 1997.

DUNN, Christopher. "Nós somos os propositores": vanguarda e contracultura no Brasil, 1964-1974. In: ArtCultura. Uberlândia, v. 10, n. 17, p. 143-158, jul.-dez. 2008.

FAVARETTO, Celso Federico. Tropicália: alegoria, alegria. São Paulo: Ateliê Editorial, 1996.

FREDERICO, Celso. A política cultural dos comunistas. In: MORAES, J. Q. (org.). História do marxismo no Brasil. Vol. III. Campinas: Ed. Unicamp, 1998, p. 275-304

FOSTER, Hal. O retorno do real: a vanguarda no final do século XX. Tradução de Célia Euvaldo. São Paulo: Cosac Naify, 2014.

FOUCAULT, Michel. Le corps utopique, les hetérotopies. Clamecy, France: Nouvelles Éditions Lignes, 2009, p. 24-25. 
Éditions Gallimard, 1975.

FRANCO, Renato. Itinerário político do romance pós-64: A festa. São Paulo: Editora Unesp, 1998.

GASPARI, Elio. A ditadura escancarada. São Paulo: Companhia das Letras, 2002.

HOLLANDA, Heloísa Buarque de Hollanda. Impressões de viagem: CPC, vanguarda e desbunde, 1960/70. São Paulo: Rocco, 1992.

(org.). Pós-modernismo e política. Rio de Janeiro:

Rocco, 1991

LEMINSKI, Paulo. Toda poesia. São Paulo: Companhia das Letras, 2013.

LYOTARD, Jean-François. A condição pós-moderna. São Paulo:

José Olympio, 2002.

MACHADO, Lizaine Weingärtner. Sob o signo do vampiro: nostorquato no brasil. In: Revista dEsEnrEdoS, n.-⒉ 23. Teresina, 2015. Disponível em $<$ http://desenredos.dominiotemporario.com/doc/23-Ensaio-LizaineTorquatoNeto.pdf >. Acesso dez. 2015.

MAINGUENEAU, Dominique. Pragmatique pour le discours littéraire. Paris: Dunod, 1997.

MARTINEZ CORRÊA, José Celso. Primeiro ato: cadernos, depoimentos, entrevistas (1958-1974). São Paulo: Editora 34, 1998. p. 320-321.

MARTINS, Luciano. A "Geração Al-5" e o Maio de 68: Duas manifestações intransitivas. Rio de Janeiro: Livraria Argumento, 2004.

MESCHONNIC, Henri. Manifesto em defesa do ritmo. Trad. Cícero Oliveira. São Paulo: Chão de Feira, 2015

Navilouca Nova Cultura, Almanaque dos Aqualoucos. Rio de Janeiro: Edições Gernasa, 1974.

NANCY, Jean-Luc. Fazer, a poesia. In: Resistência da poesia. Trad. Bruno Duarte. Lisboa: Vendaval, s/d. 
NETO, Torquato. Os últimos dias de Paupéria. Organização de Waly Salomão e Ana Maria S. de Araújo Duarte. Rio de Janeiro: Livraria Eldorado Tijuca, 1973.

OITICICA, Hélio. Aspiro ao grande labirinto. Rio de Janeiro: Rocco, 1996. Brasil diarreia. Disponível em <http:docslide.com.br/ documents/brasil-diarreia.html>. Acesso dez. 2015 (publicado originalmente em Arte em Revista, maio de 1971).

OLIVEIRA, Fabrício Marques de. Paulo Leminski e Torquato Neto: dois “kamiquases”. Disponível em <http://www.elsonfroes.com.br/kamiquase/ ensaio25.htm>. Acesso em dez. 2015.

PATROCÍNIO, Paulo Roberto Tonani do. O que há de positivo em ser marginal? Disponível em <http://www.abralic.org.br/eventos/cong2011/AnaisOnline/ resumos/TC0115-1.pdf>. Acesso em dez. 2015.

RIBEIRO, Elzimar Fernanda Nunes. Vampiros e outras assombrações: imagens do medo na poesia de Torquato Neto. Disponível em <http://www4.pucsp. br/ revistafronteiraz/numeros_anteriores/n5/download/pdf/30_08_2010_ Torquato.pdf>. Acesso em dez. 2015.

ROSZAK, Theodore. El nacimiento de uma contracultura. Reflexiones sobre la sociedad tecnocrática y su oposición juvenil. Barcelona: Editorial Kairós, 1981.

SALOMÃo, Waly. Poesia total. São Paulo: Companhia das Letras, 2015.

SIMON, I. M. , DANTAS, V. Poesia ruim, sociedade pior. In: Novos Estudos Cebrap (São Paulo), n. 12, p. 48-61, 1985.

SCHWARTZ, Roberto. Cultura e Política, 1964 - 1969. In: O pai de família e outros estudos. Rio de Janeiro. Paz e Terra, 1978. p. 61-92.

SGANZERLA, Rogério. Cinema Fora-da-lei. Manifesto escrito em 1968 durante as filmagens de O bandido da luz vermelha. Disponível em: <http://www.contracampo.com.br/27/frames.htm>. Acesso em: dez. 2015.

SÜSSEKIND, Flora. Coro, contrários, massa: a experiência tropicalista e o Brasil de fins dos anos 60. In: BASUALDO, Carlos (org.). Tropicália: uma revolução na cultura brasileira. São Paulo: Cosac Naify, 2007, 31-56. 
Literatura e Vida Literária: polêmica, diários e retratos.

Rio de Janeiro: Jorge Zahar Editora, 1985.

VÁRIOS AUTORES. Anos 70: trajetórias. São Paulo: Itaú Cultural e

Iluminuras, 2005.

VELOSO, Caetano. Verdade tropical. São Paulo: Companhia das Letras, 1997.

VENTURA, Zuenir. "O vazio cultural” In: GASPARI, Elio; HOLLANDA, Heloisa Buarque de \& VENTURA, Zuenir (orgs.). Cultura em trânsito: da repressão à abertura. Rio de Janeiro: Aeroplano, 2000, p. 40-51.

VIEIRA, Beatriz de Moraes. A palavra perplexa: experiência histórica e poesia no Brasil nos anos 1970. São Paulo: Hucitec, 2011, p. 170

VIEIRA, Beatriz de Moraes. Torquato Neto, o cogito e os dentes. In: PEDROSA, Célia; ALVES, Ida (orgs.). Subjetividades em devir. Estudos de poesia moderna e contemporânea. Rio de Janeiro: 7letras, 2008, p. 24-32.

XAVIER, Ismail. Alegorias do subdesenvolvimento. Cinema novo, tropicalismo, cinema marginal. São Paulo: Editora Brasiliense, 1993.

ZULAR, Roberto. O que fazer com o que fazer? Algumas questões sobre Me segura qu'eu vou dar um troço, de Waly Salomão. In: Revista Literatura e Sociedade, n. 8. São Paulo: FFLCH/USP, 2005, p. 46-59.

ZUMTHOR, Paul. Performance, recepção, leitura. São Paulo: Cosac Naify, 2007. 